IRA-International Journal of Management \& Social Sciences

ISSN 2455-2267; Vol.08, Issue 03 (September 2017)

Pg. no. 232-247

Institute of Research Advances

http://research-advances.org/index.php/RAJMSS

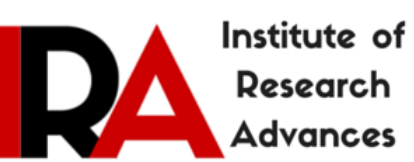

\title{
Corporate Governance Practices of Family Enterprises: A Study on Some Selected Indian Family Governed Companies
}

\author{
Dr. Amit Majumder \\ Assistant Professor of Commerce, Bijoy Krishna Girls' College, Howrah \\ Guest Faculty, Dept. of Commerce, University of Calcutta, India.
}

Type of Review: Peer Reviewed.

DOI: http://dx.doi.org/10.21013/jmss.v8.n3.p2

\section{How to cite this paper:}

Majumder, A. (2017). Corporate Governance Practices of Family Enterprises: A Study on Some Selected Indian Family Governed Companies. IRA-International Journal of Management \& Social Sciences (ISSN 2455-2267), 8(3), 232-247. doi:http://dx.doi.org/10.21013/jmss.v8.n3.p2

(C) Institute of Research Advances.

\section{(cc) $\mathrm{EY}-\mathrm{NO}$}

This work is licensed under a Creative Commons Attribution-Non Commercial 4.0 International License subject to proper citation to the publication source of the work.

Disclaimer: The scholarly papers as reviewed and published by the Institute of Research Advances (IRA) are the views and opinions of their respective authors and are not the views or opinions of the IRA. The IRA disclaims of any harm or loss caused due to the published content to any party.

Institute of Research Advances is an institutional publisher member of Publishers Inter Linking Association Inc. (PILA-CrossRef), USA. The institute is an institutional signatory to the Budapest Open Access Initiative, Hungary advocating the open access of scientific and scholarly knowledge. The Institute is a registered content provider under Open Access Initiative Protocol for Metadata Harvesting (OAI-PMH).

The journal is indexed \& included in WorldCat Discovery Service (USA), CrossRef Metadata Search (USA), WorldCat (USA), OCLC (USA), Open J-Gate (India), EZB (Germany) Scilit (Switzerland), Airiti (China), Bielefeld Academic Search Engine (BASE) of Bielefeld University, Germany, PKP Index of Simon Fraser University, Canada. 


\begin{abstract}
Corporate governance implies how an organization is directed and controlled under a set of mission, values, and philosophy (Cadbury, 1992). But unfortunately, over time, the common investors all over the globe have suffered a lot in the hands of the greedy managers and scams like Enron, Adelphia, Tyco, Worldcom, Xerox, Paramalt, and Satyam have shattered the trust in the very mechanism of corporate management and governance. However, despite a lot of initiatives had been taken around the world in the form of codes/laws for ensuring good governance for corporate sector, the issue of governance practices of family enterprises operating in India had not been discussed in detail. But, in view of the contribution of the family enterprises to Indian Economy over the years, a renewed interest on their governance mechanism is the need of the hour. Starting from Tata to Birla, Ambani, Goenka, Ruia, Mittal etc. Corporate India had a long heritage of domination of family governed firms. They contribute significantly towards economic growth of the country, employment generation, boosting up Gross Domestic Production as well as accumulation of foreign reserve through growth in export and also engaged into cross border Merger and Amalgamations. However, time and again the issues of governance and succession policy had perturbed the smooth sailings of these family governed firms in India. Recent examples like clash between Ambani brothers, inheritance issues in Birla clan proved that case. Against this backdrop the present study is a humble attempt to enquire the state of affairs of corporate governance in major family governed firms in India.
\end{abstract}

Keywords: Family Enterprises; Family Governance.

\title{
Prologue
}

The word good governance is a current buzzword not only in management literature, but also in every walk of public administration and public life. Every stake holders in all kinds of enterprise expects good governance prevailing in the concern. However the word "Governance" has a Latin route "Gubernare", which denotes "to steer". Corporate Governance might therefore be interpreted as related to the guidance of a company's affairs. There have been significant changes in the economic and business scenario all over the world in last decade. India has been exception. Trade barriers have been lifted, caps on FDI and FPI are removed on different core and non-core businesses, the world is becoming a smaller market, bottom lines are talking precedence and quality is the buzz word to survive in the competitive environment. Corporate now have access to opportunities worldwide. At the same time, they are also faced with threats of their own survival with the entrance of global player in India. In India, corporate scams and scandals of huge dimensions are surfacing; Harshad Mehta scam, Ketan Parikh scam, Tata Finance, IPO scam, recently held Satyam scam and so on to name a few. Resources are becoming scare and attention is therefore being given to development of greater skills. All these are good for investor as well as customer and in the long run into the corporate themselves.

Therefore, for survival and growth, adherence to some nationally and internationally accepted Corporate Governance codes which prescribe good corporate governance measure is a pre-requisite. These factors have also created a general awareness on the part of investor and lending institution. These entire factors necessitated a paradigm shift in the way the corporate are governed in order to achieve self-discipline and "serving the best interests of all". On the other hand, family businesses have many things going for them - they tend to be flexible, reliable, and proud, they can think long-term, have a strong culture and their people are committed. But they can also carry a daunting set of disadvantages - they can be rigid, inward-looking, and unresponsive to change and sometimes swamped by emotional issues. It's a fascinating and complex mixture of advantages and disadvantages, costs and benefits, strengths and weaknesses.

The larger a business-owning family becomes the more complex and diverse it becomes; and developing the skills required to forge a common agenda and resolve differences among family shareholders involves great challenges. Creating effective and transparent governance enables discussion and resolution of the complicated and often emotional family, ownership and business issues that confront mature family companies. Family members, therefore, need to devise strategies that help them to approach the business in a unified way, and they need to learn to communicate and share their thinking about the critical issues the family must face up to. Starting from Tata to Birla, Ambani, Goenka, Ruia, Mittal etc., corporate India had a long heritage of domination of family governed firms. They contribute significantly towards economic growth of the country, employment generation, boosting up 
Gross Domestic Production as well as accumulation of foreign reserve through growth in export and also engaged into cross border Merger and Amalgamations. However, time and again the issues of governance and succession policy had perturbed the smooth sailings of these family dominated firms in India. Recent examples like clash between Ambani brothers, inheritance issues in Birla clan proved that case. In this backdrop the present study is a humble attempt to enquire the state of affairs of corporate governance in major family dominated firms in India.

\section{Governance of family dominated firms: a few rudimentary thoughts:}

In family governance, the definition of "family" is necessarily broader than a group of persons related solely by blood or marriage. In a governance system, "family" can also include close friends or professional advisors who have developed intricate and intimate relationships with individual family members. Family-owned firms are one of the foundations of the world's business community. Their creation, growth and longevity are critical to the success of the global economy. Although facing many of the same day to-day management issues as publicly-owned companies, they must also manage many issues specific to their status.

Sir Adrian Cadbury's long and distinguished business career was built on his dual expertise in both corporate governance and family firms. A recognized authority on the former, he led the committee which laid the foundations for corporate governance in the UK. Thereafter, he played a crucial role in developing corporate governance standards in many other countries. Sir Adrian also has a first-hand understanding of family firms. His career began with his own family's firm, the Cadbury company. Joining its board when it was still privately owned, he subsequently became its chairman. During his tenure, Cadbury was transformed into a public company and subsequently merged with Schweppes.

Successful family businesses have one thing in common they are well governed and managed. Broadly speaking, a family's governance structure comprises the rules and systems under which its business and wealth are held and preserved, and under which the family and its members, fiduciaries and advisers can work together to give the family its own articulated creed and vision. Guidelines will be established for all family members to follow. A good governance structure will look to achieve organized accountability and a clear balance of power among the various interests and bodies that comprise a family and its business. These will include family members, company shareholders and directors, fiduciaries family advisers and possibly the family office. It is important that any system of governance be given the time and space to develop naturally out of family discussions, and be driven by a family's vision and ethos. This will help to ensure that it is tailored to the individual needs of each family. Family businesses that reach the third generation generally share some unique qualities. They tend to think longer term, favor profit reinvestment rather than dividend payouts, and they often engender a special atmosphere - a sense of belonging, common purpose, pride and commitment - that has been passed down and inculcated from one generation to the next.

But mature family businesses are also prone to serious disadvantages. They are much more complex entities than their non-family counterparts because of the central role played by the families that own and often lead them. Because many of the problems they encounter hinge on the inherent conflicts that can arise between emotion-based family values and task-based business values, looking at family businesses in the context of competing value systems provides an excellent starting point to gaining an understanding of their complicated dynamics. The differing purposes and priorities of owners cum managers and owners, managers alone produce some special tensions that exist in family firms, creating at the point of overlap operational friction and value conflicts for the large number of family members involved, either in an ownership or management capacity.

\section{Complexity in Family Businesses:}

Family businesses are constantly changing and evolving around the world rapidly around the key areas that impacts particularly severely on multi-generational family enterprises - the way that ownership dynamics tend to develop over time. A few issues in this regard are as follows-

- Number Game- When the family business grows three or four generations, it is quite possible for there to be more than fifteen grandchildren of the founder, and, in total, there can be more than thirty members of the family with some sort of stake in the business. The growing number of members naturally begot complexity in ownership and management issue. 
- Branch Dominance- As the family governed companies grows, management locus of the business generally shifts from single-branch management process to multi-branch founding family. It may be reassuring to some relatives that the wealth and commercial prestige of the family is being taken forward by this branch, but any skill shortages of the branch and how its members exercise their authority can generate tensions and resentment.

- Historical Baggage- In some family governed companies, however, the passing of time has no such soothing effect on the cousin generation, and old grievances can loom large, magnified by the weight of history and constant re-telling. Indeed, members of the senior generation sometimes go to extraordinary lengths to keep alive old grudges and complaints that serve little purpose other than to magnify and perpetuate family divisions and undermine trust and confidence in succeeding generations.

- Emotional Hiccups- In some family governed companies, emotion-based rivalries (like father-son, sibling, cousin rivalries) may cause a serious problems in the management and governance of these enterprises. Recent examples in Indian corporate sector like Reliance Industries Ltd., Birla Clan proves this issue.

- Ownership Politics and 'Migration'- As family businesses evolve and their owning families become more complex, a migration takes place towards ownership by family members who are increasingly remote from the operations of the business. This causes a real tension over management affairs of these organizations.

- Divergent Interests- In various family governed companies, the needs, expectations and ambitions of owners running the business can be different from those who are not employed by the firm. The latter, for example, relying on dividend income to maintain lifestyle expectations formed in earlier, smaller generations, may oppose any reduction in dividends, even if that money is to be reinvested for future growth of the business. In contrast, the spouses of share-owning relatives working in the business may feel that their partners are being under-rewarded and their careers undermined by the regular payout of dividends to shareholders not involved in day-to-day operations.

- Control Retention- When the family governed company takes a drastic measure for inculcating the professionalization in management affairs of these firms by allowing the company to be led by the nonfamily senior executives, the issues like retention of locus of control of firm within family and the problem of motivation of non-family senior personnel of naturally arises.

- Information Flows- Most insider shareholders in family governed companies are not employed in the family business, and, over time, they come to feel they are receiving less and less direct information about it. Whereas once they used to have regular reports from involved parents, spouses or children that served to keep them in touch with events and able to feel protective of the interests of their branch of the family, they are now subject to the company's shareholder communication policies. Often there are issues concerning the consistency and reliability of information, with different branches "hearing" different things.

\section{Remedies of growing complexity in family business:}

The challenges in management of family-governed companies can be address mainly by two ways: (a) reducing complexity by buying-out cousins and consolidating ownership of the business in far fewer hands; or (b) to retain the complexity, in which case it has to be carefully managed to prevent it running out of control. A few effective measures for reducing the complexities in governance of family business are as follows-

- Constructing the Family Council: The family council is the main forum through which the distinctive interests and concerns of family members and shareholders can be articulated. At its best, a family council in a multi-generational business probably has up to 10 elected members representing all family members, generations and branches. It is a working group serving as an 'executive' committee of the family assembly. The family council will operate as a 'bridge' between the board of directors and the family shareholders. In family businesses, the board of directors has an extra area of responsibility beyond those in non-family enterprises (which centre on maximizing shareholder value). Board members must understand the family's relationship with the company, mediate its influence on the firm and help ensure that the family's reasonable long-term goals for the business are met. The council, which may include family managers as well as family owners, should operate on a consensus basis, not by majority vote or in accordance with shareholding. The council has no formal business authority, but it aims to create the family 'glue', enabling the family to speak with one voice to the board.

- Family assembly:-This is an open forum for all family shareholders or all family members from the different Branches of the family to meet and discuss family issues and concerns relating to the business, and to learn and ask questions about its activities. Assembly meetings should be scheduled to maximize 
attendance, and are often combined with social activities. They provide an opportunity for accountability, with family leaders who work in the family governance process able to report back to the wider family. Family assemblies should also aim to teach family members about the business through Presentations, and to discuss in broad terms the direction the company is taking and how this might change in the future.

- Promoting family harmony:-Managing complexity requires introducing 'structure' in the form of rules, policies and procedures that help the family develop a cohesive approach to its involvement in the business. In short, what's needed is effective governance, which means creating organized accountability and alignment among the different interests of the owners, the family and the business. Businesses in India generally have a visionary leader or guru who works to foster harmony by working with the family to help resolve their disagreements and conflicts. The guru - chosen for his wisdom and shrewdness - will often attend family council meetings and, if he foresees potential problems that may lead to family divisions, he will follow-up the situation outside the meeting to ensure that friction and arguments are minimized or avoided.

- A council of elders:- As well as family councils and assemblies, the family governance architecture in many Middle Eastern family businesses includes an extra body - a council of elders or seniors. Because of deep-seated respect for the senior generation that underpins many aspects of Middle Eastern life and culture, this entity will be at the top of the family governance hierarchy, with the family council acting as its executive committee.

- Family office:-The role of the family office is to centralize functions for family members and, by acting as an investment, liquidity management and administrative centre, it helps underpin the family governance structure. It can also oversee family estate and tax planning, and coordinate insurance, banking and accounting. Many families believe stronger family ties will develop for future generations when a dedicated office exists, because it helps foster a strong family identity, clarifies family values, preserves traditions and trains young people to responsibly manage the money they will one day inherit. The family office is a separate operation from the family business, although some of the same individuals may participate in both. It should have a formal business structure with a management board (which can consist of family members as well as outside advisers) and it should report to the family on investment performance, liquidity and other operating information. Through planning together, a family can create a shared vision and an articulation of principles and guidelines that will help direct overall investment policies.

- Family socials committee:-This body organizes regular events that are designed to support and strengthen family Governance by fostering family relationships. Special efforts are often needed for distant Cousins to get to know each other, helping to build a stronger and more cohesive family unit. Staffing options include open election, volunteers only, outgoing seniors picking their replacements, family branches choosing personnel and nominating committees making selections.

\section{Objectives of the Study:}

Against this backdrop, the objective of the present study is to appraise the state of affairs of governance practices of large family enterprises operating in India.

\section{Research Methodology: \\ Research Design}

In order to analyze the current governance practices of large family enterprises, the present study is conducted on those listed Indian Companies of Bombay Stock Exchange which are responsible for composition of SENSEX, a major indicator of Indian economy's performance. Hence, the sample size of the study was 30 major listed Indian companies responsible to construct BSE SENSEX as on 31.03.2014. Among these top 30 listed firms of S\&P BSESENSEX 14 large firms had the tradition of family run management style namely, Bajaj Auto, Bharti Airtel, Reliance Industries Ltd, Mahindra \& Mahindra, Tata Motors, Tata Steel, Tata Powers, Tata Motors, Tata Consultancy Services, Cipla, Hero Motocorp, Dr.Reddy's Laboratories Ltd, Hindalco Industries, Wipro and Sun Pharmaceuticals Industries Ltd.

For the purpose of the study, the following governance vectors have been considered viz. board structure, frequency of meetings of board, nature, formation and effectiveness of different committees e.g. Audit Committees, Remuneration Committees, Investor Grievance Redressal Committees, Nomination or Corporate Governance Committees, Market Capitalization (M-Cap), employee grievance redressal mechanism, Corporate Social Responsibility (CSR), complaints against the company / SEBI Stricture etc. Moreover, correlations between 
implementation of corporate governance codes and financial performance of the companies are measured on these variables viz. Profit after Tax (PAT), PAT/Total Assets, Market Capitalization, etc.

\title{
Data Source
}

Data were collected mainly from the secondary sources. The secondary data for this present study was based on PROWESS Corporate Database provided by the Center for Monitoring Indian Economy (CMIE), Mumbai, a nationally acclaimed premiere corporate data mining house. Moreover, corporate annual reports, research publications, books, journals, reports in newspapers, electronic newsletters of different professional institutions as well as corporate houses, websites of the companies, publication of corporation rankings by different Indian as well as different international agencies were also consulted as and when required.

\section{Scheme of Investigation}

The present study was aimed to examine the general degree of compliance of Corporate Governance Codes by selected major Indian Companies. Here, 95 significant recommendations from 22 nationally and internationally accepted codes of Corporate Governance are selected viz.

\section{Indian Codes/ Law for promoting Good Corporate Governance:} CII Charter (1998), K.M. Birla's recommendation/Clause 49 of listing agreement of SEBI (1999), Naresh Chandra Committee's recommendations on Corporate Audit and Governance (2002), Narayana Murthy Committee Report (2003), J.J. Irani Committee Report (2005), and

\begin{abstract}
Some Highly Acclaimed International Codes/Law for promoting Good Corporate Governance: Cadbury Report (U.K., 1992), Greenbury Report (U.K., 1995), Viénot II Report (France, 1999), Commonwealth Association of Corporate Governance(CACG) Guidelines / Principles for Corporate Governance in the Common wealth (Commonwealth, 1999), Combined Code of London StockExchange (U.K., 2000), Euroshareholders Guidelines (Europe, 2000), Code of Corporate Governance for listed companies in China (China, 2001), TIAA-CREF Policy Statement on Corporate Governance (U.S., 2000), Norby Committee's Report on Corporate Governance (Denmark, 2001), Sarbanes-Oxley Act (U.S., 2002), Hermes Principles (U.K., 2002), King II Report (South Africa, 2002), The Cromme Code (Germany, 2002 \& 2003), NYSE Listing Standard (U.S., 2003), Securities Exchange Commission Listing Rules (U.S., 2003), Higgs Report (UK,2003), Smith Report (UK, 2003), International Corporate Governance Network(ICGN) Statement on Global Corporate Governance Principles (ICGN, 2005), Revised Combined Code of London StockExchange (U.K., 2006) etc.
\end{abstract}

\section{Summary of Findings:}

Some of the significant observations emanated from this survey conducted on the Family Enterprises in S\& P BSE SENSEX companies are presented below.

\section{(i) Compliance of Codes:-}

Regarding compliance of mandatory provisions of Clause 49 of listing agreement (originated from the recommendations of Kumar Mangalam Birla Committee) the surveyed family governed companies showed almost cent percent performance; and so far as recommendatory performance was concerned, the surveyed companies had shown commendable performance.

\section{(ii) Board Size:-}

The Average Board Size of the surveyed family enterprises of S\&P BSE SENSEX is 12 with standard deviation 2.075. On the other hand, the average board size of non-family enterprises stands at 12.375 with s.d. 2.70. 


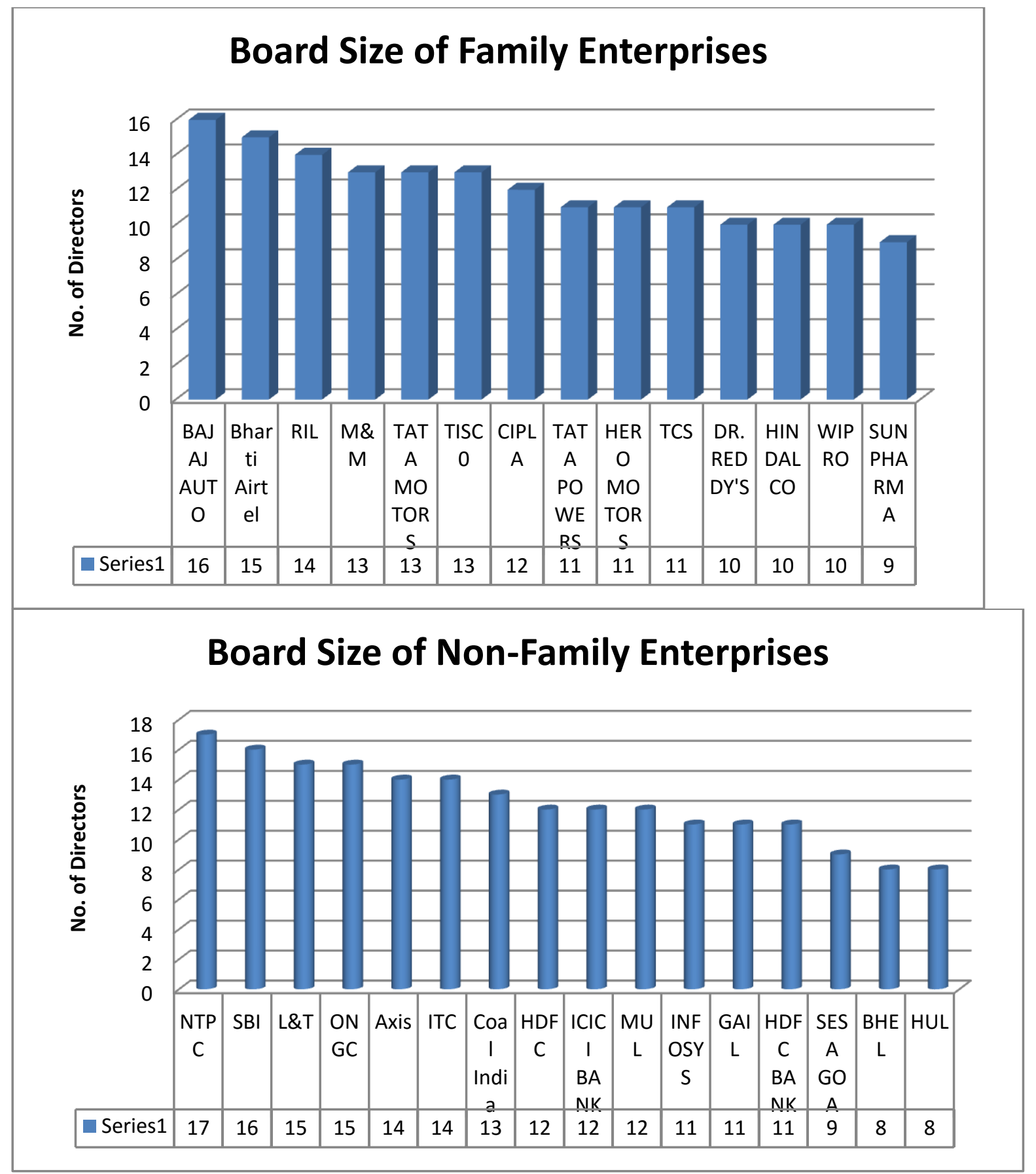

\section{(iii) Independence of Board:-}

In respect of promoting independence to the board in the family enterprises, it was found that all the family enterprises had at least $1 / 2$ of the board composed of Independent Directors (thanks to the mandatory recommendation of Clause 49 of listing agreement that $1 / 2$ of the board should consist of non-executive independent directors, if its chairman is an Executive Director). But, if we consider the recommendation of Naresh Ch. Committee, appointed by Dept. of Company Affairs, that majority of the board should consist of Independent Directors then 9 out of the 14 surveyed family enterprises had fulfilled such norm. 


\section{(iv) Status of Chairman of the Board:-}

It was found that 8 out of 14 surveyed family enterprises had Non-Executive Director as the Chairman and the rest 6 had Executive Director as the Chairman of the Board.

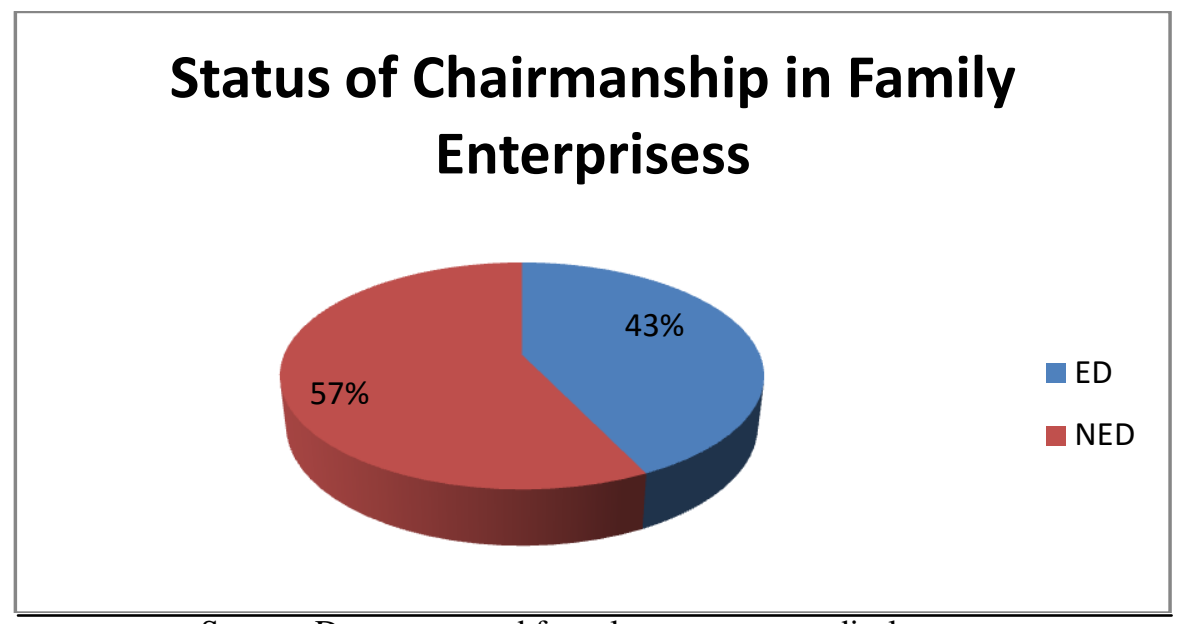

Source: Data computed from latest corporate disclosures

On the other hand, if we look into the status of chairman in non-family enterprises, exactly $50 \%$ i.e. 8 out of the 16 non-family enterprises in S\&P BSE SENSEX has non-executive directors at the helm of the board.

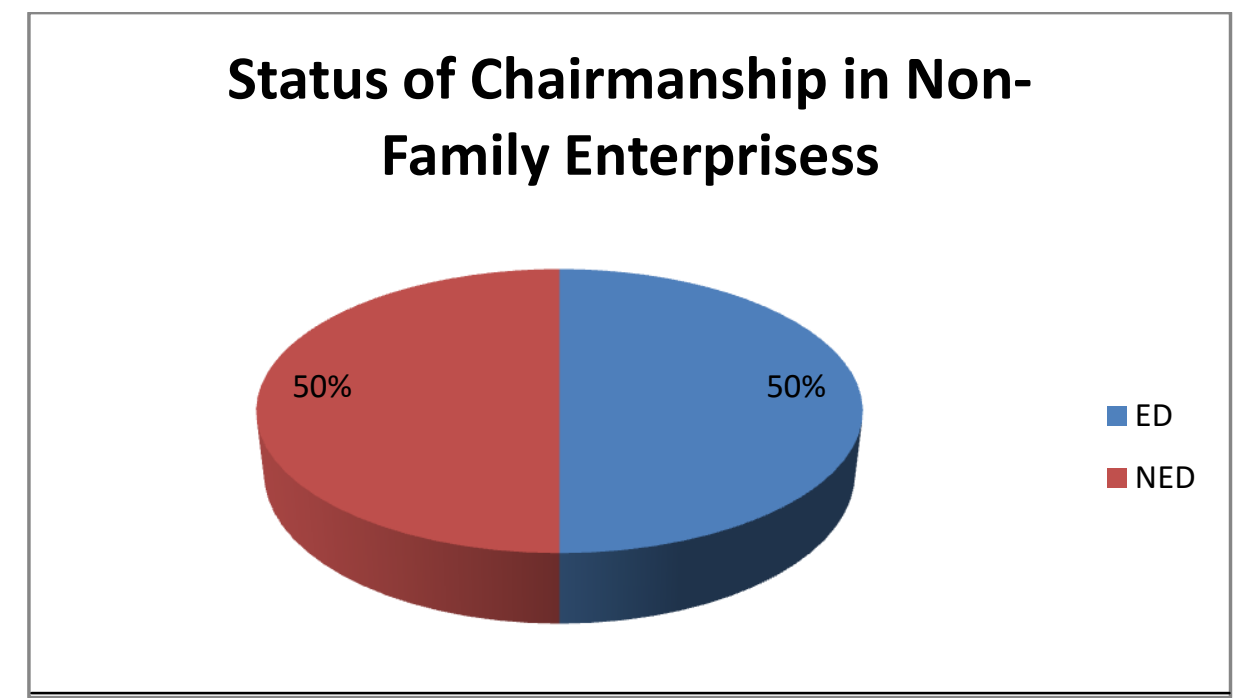

Source: Data computed from latest corporate disclosures

(v) Separation of Role of Chairman and CEO:-

In this front the 10 out of 14 surveyed family enterprises had separated the role of Chairperson and CEO. However, as far as non-family enterprises are concerned, 10 out of 16 surveyed non-family enterprises had separated the role of Chairperson and CEO. 


\section{Seperation of the Role of Chairman and CEO of Family Enterprises}

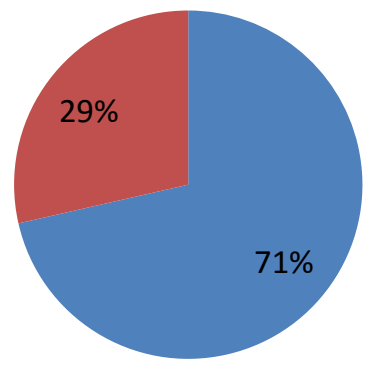

Source: Data computed from latest corporate disclosures

\section{Seperation of the Role of Chairman and CEO of Non-Family Enterprises}

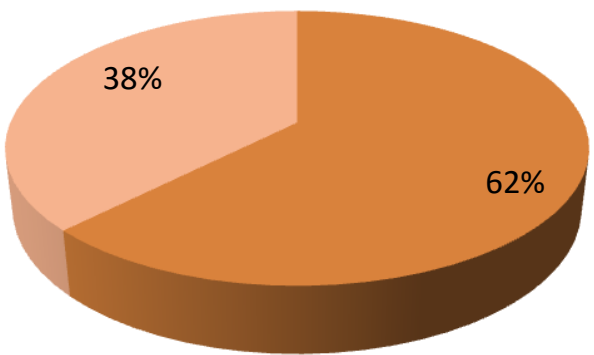

Source: Data computed from latest corporate disclosures

(vi) Gender Diversity in Board:-

The New Act requires every listed company and every public company - with a minimum paid up share capital of Rs 100 crore or an annual turnover of at least Rs 300 crore, is required to appoint a woman director. However, in this front S\&P BSE SENSEX Companies fail miserably. Only 3 out of the top 30 companies had more than 2 women directors in Board while 7 had no female representations in boards. But we have the example of Arundhati Bhattacharya, the Chairperson of SBI, who is the first woman to be appointed to the top job at the country's largest lender. Recently prestigious business magazine Forbes had put Ms. Bhattacharya, a Jadavpur University alumnus as one of top powerful business women in Asian subcontinents. 


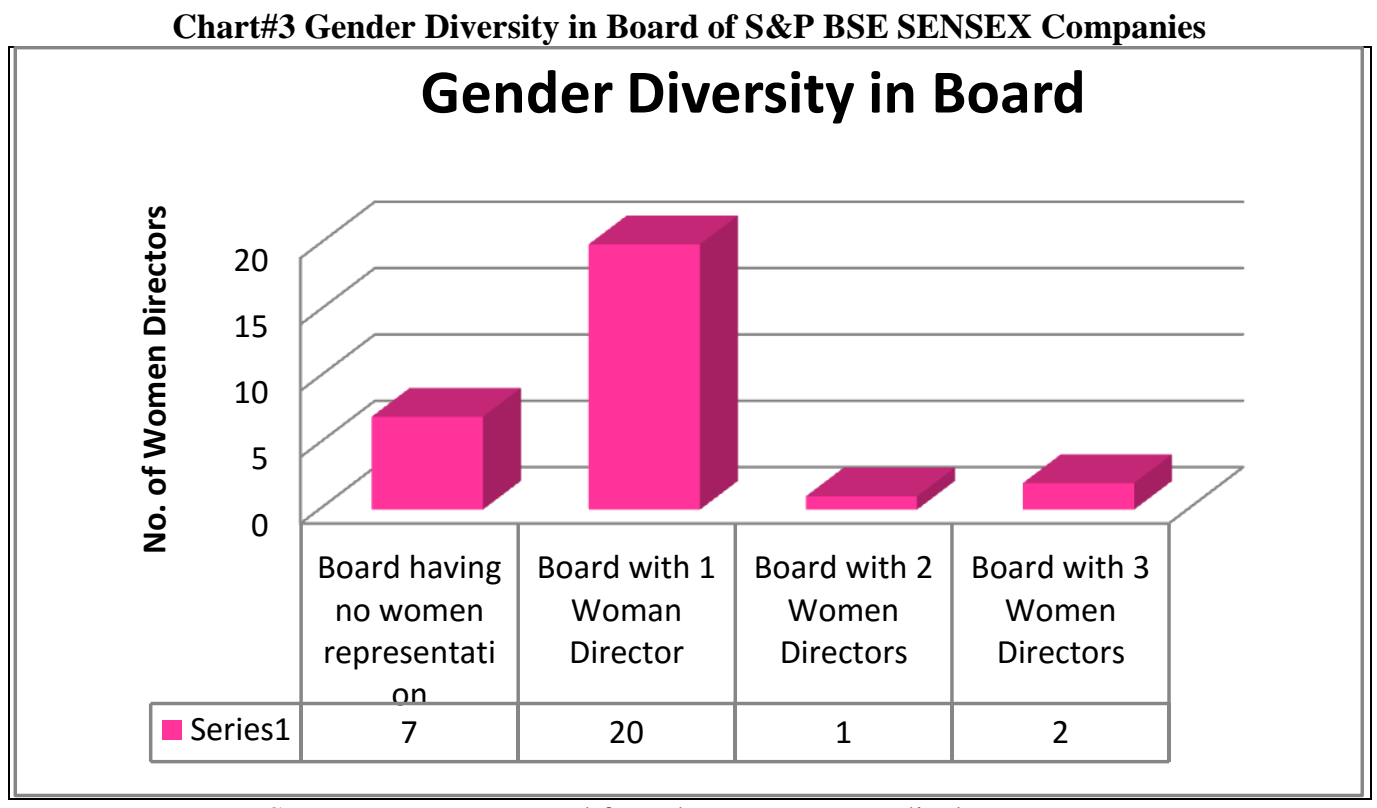

Source: Data computed from latest corporate disclosures

So far as gender representation in board of the family enterprises is concerned it is observed that 12 out of 14 major family enterprises in S\&P BSE SENSEX had at least one woman in the board position.

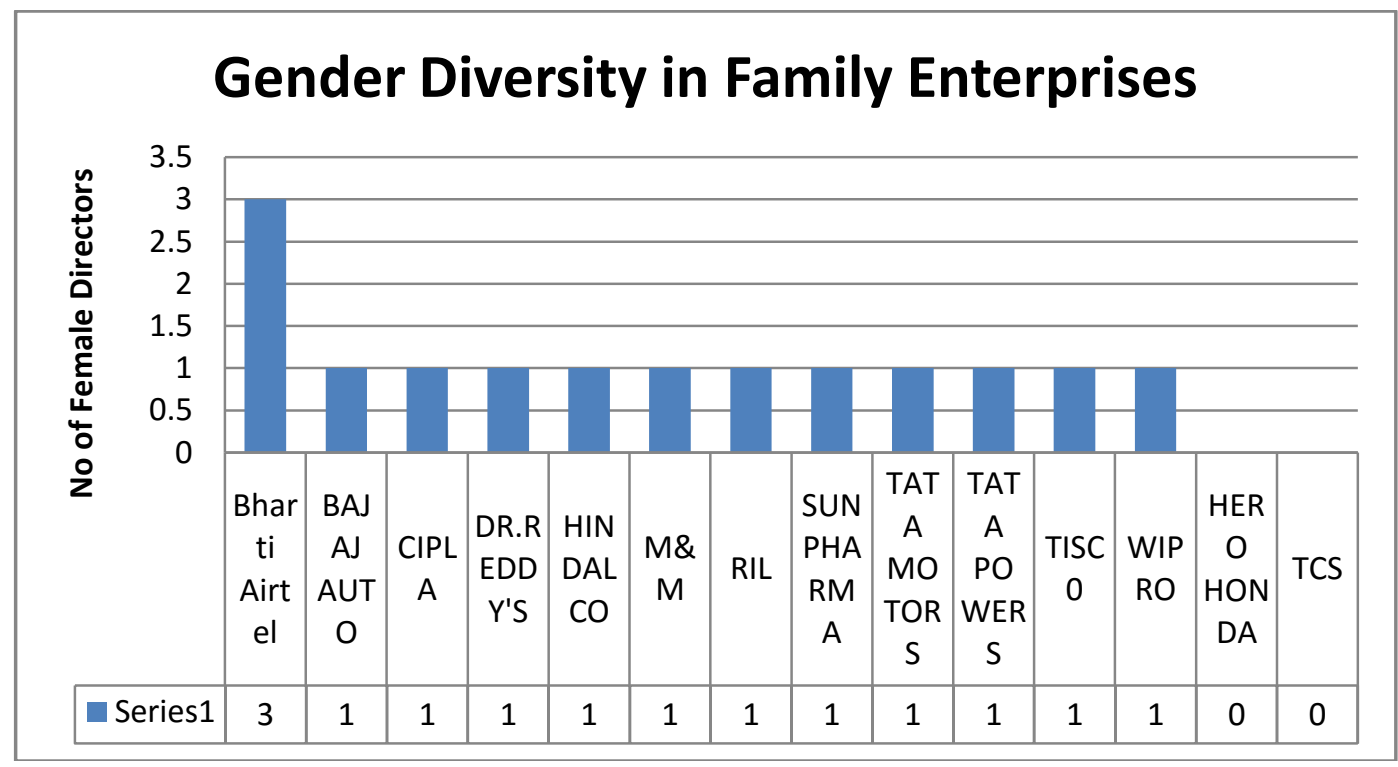

Source: Data computed from latest corporate disclosures

However, on the other hand, 14 out of 16 non-family enterprises it was observed that 14 out of 16 major nonfamily enterprises in S\&P BSE SENSEX had at least one woman in the board position. 


\section{Gender Diversity in Non-Family Enterprises}

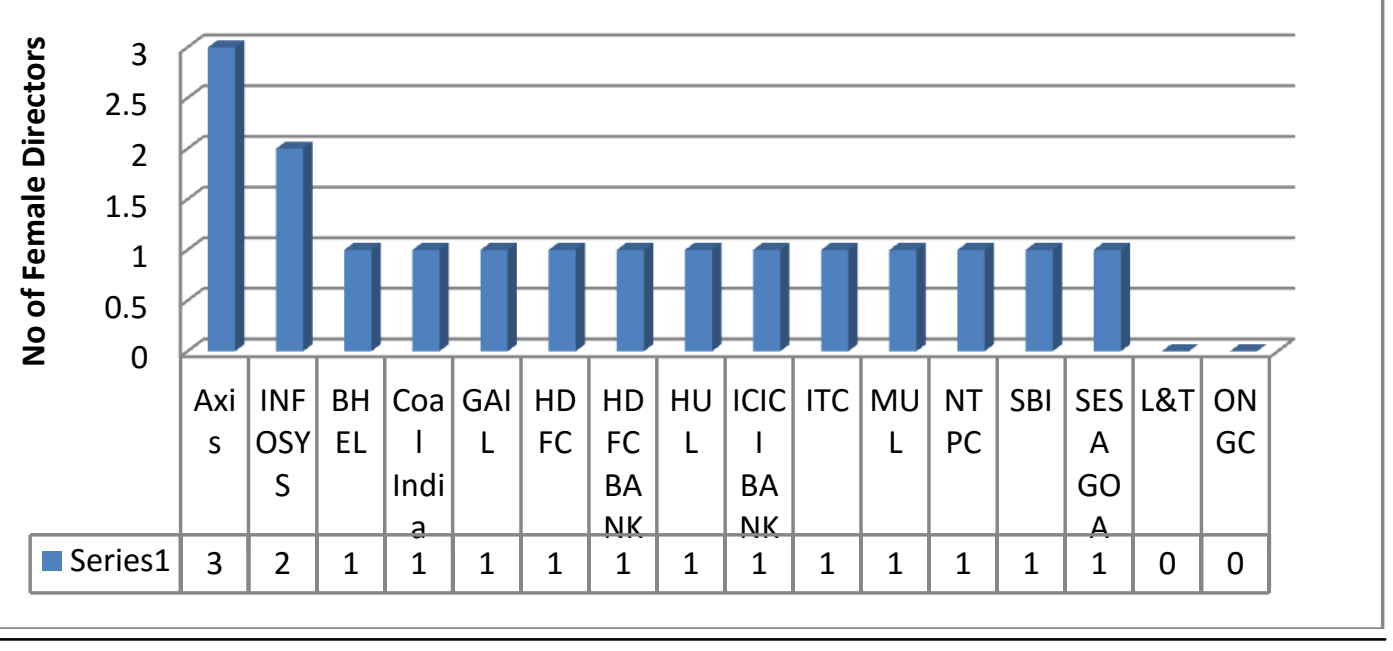

Source: Data computed from latest corporate disclosures

(vii) Composition of Audit Committee:-

It was found that $78.57 \%$ family enterprises (11 out of 14) had Audit Committees (AC) composed exclusively of Independent Directors (IDs) and 12 out of 14 family enterprises' audit committees have disclosed formal written charters that are approved by the full board of directors. However regarding review and reassess the adequacy of the audit committee charter on an annual basis by the board, only $14.29 \%$ ( 2 out of 14) companies followed this issue. But, it was found that all the surveyed companies had all if not, at least one member with strong background in accounting and financial discipline. Moreover, all the surveyed companies did not appoint any person who was the former member of executive board as the Chairman of AC.

(viii) Functioning of Board \& Audit Committee:-

Regarding meetings of board and audit committee all most all the companies had a minimum four board meetings in each year with a time gap of not more than 4 months between any two Board meetings as well as they had also organized meeting for Audit Committees-once every 6 months and once before finalization of accounts.

But, regarding disclosure of minutes of Board meeting and AC meetings in annual reports exactly $1 / 2$ of the family enterprises ( 7 out of 14 ) maintained it. Moreover, only $35.71 \%$ of surveyed family enterprises (5 out of 14) had organized a separate meeting for audit committees with the external and internal auditors of the company at least once in a year, without management, to discuss issues arising from the audit and 85.71.\% of the family enterprises (12 out of 14) had conferred increased responsibility to AC to hire \& fire both internal/external auditors.

(ix) Meetings of NEDs separately:-

For promoting transparent and effective corporate governance it was prescribed (Review of the role \& effectiveness of NEDs, Higgs Report,U.K.,2003) that the non-executive directors should meet as a group at least once a year without the chairman or executive directors presence and the annual report should include a statement on whether such meetings had occurred. In that particular issue, a highly discouraging performance by the surveyed Indian family enterprises had been observed-only 4 out of the 14 family enterprises of S\&P BSE SENSEX (30\%) had organized such a meeting.

(x) Composition of Remuneration Committee:-

Regarding composition of Remuneration Committee fully by at least 3 Non-Executive Directors, $78.57 \%$ of surveyed family enterprises (11 out of 14) adhered to the issue. Besides, $57.14 \%$ of the surveyed family enterprises' Chairmen of Remuneration Committees ( 8 out of 14 companies) were present in Annual General Meeting to respond queries. Moreover, regarding the issue of Remuneration \& Appraisal Committee to study the appraisal standard for directors and management personnel and to make recommendations, only 6 out of the 14 surveyed family enterprises had complied with it. 
(xi) Disclosure of Executive Remuneration Package:-

All the surveyed family enterprises had disclosed the remuneration of corporate officers by breaking down into fixed and variable part. However, regarding disclosure of pension entitlements earned by each individual director during the year $64.29 \%$ of the surveyed family enterprises ( 9 out of 14 companies) had followed this issue.

(xii) Nomination Committee:-

It was revealed that only 9 out of 14 family enterprises had a Nomination Committee. Regarding appointments to the audit committee made by the board on the recommendation of the nomination committee in consultation with the audit committee chairman, 5 out of 14 surveyed family enterprises adhered to it. However, one of the codes (Combined Code of Corporate Governance,U.K.,2006) of promoting good corporate governance prescribed that the chairman or an independent non-executive director may chair the nomination committee, but the chairman should not chair the nomination committee when it is dealing with the appointment of a successor to the chairmanship. On this front, 8 out of the 14 family enterprises $(57.14 \%)$ had followed such issue.

(xiii) Investors Grievance Committee:-

All the companies including family enterprises (100\%) had established a separate Investors Grievance Committee under the chairmanship of a non-executive director in line with the provision of Clause 49 of Listing Agreement.

(xiv) Corporate Social Responsibility Committee:-

In pursuance to Sec. 135 of New Companies Act, 2013 and vide Cl. 55 of Listing Agreements, all the major listed companies including family enterprises in S\&P BSE-SENSEX have started to properly constitute a Corporate Social Responsibility Committee comprising of at least three directors with one Independent Directors to formulate and recommend to the Board, a Corporate Social Responsibility Policy, which shall indicate the activities to be undertaken by the company as specified in Schedule VII and to recommend the amount of expenditure to be incurred on the CSR activities.

(xv) Corporate Disclosure:-

Regarding disclosure of price sensitive information and communication of information through electronic media, all the surveyed companies had gone for such disclosure through their official websites and/or electronic newsletters or electronic media.

Moreover all the surveyed family enterprises had disclosed the number of stock held by each director in his or her personal capacity in the corporation concerned through their annual report, 'investor service' section of their homepages and in notice calling the meeting of shareholders. Besides, all the companies had also disclosed the stock-option or stock-purchase plans offered towards both white collar and blue collar employees.

(xvi) Whistle Blower Policy:-

It was believed that in order to promote good corporate governance, the existence of "Whistle Blower Policy" in terms and conditions of service contract of employees should be there. In the present survey it was found that only 13 out of 14 family enterprises (had followed such issue.

(xvii)Performance Evaluation of Directors and Board:-

It was found that only 3 out of the 14 surveyed family enterprises $(21.43 \%)$ had gone for performance evaluation of non-executive directors by a peer group comprising the entire Board of Directors, excluding the director being evaluated. The similar circumstances had happened in review and reassessment of the adequacy of the audit committee charter on an annual basis where only 2 out of all surveyed family enterprises (14.29\%) had followed such an important issue. Moreover, regarding disclosure of whether directors were participating in director training and orientation programs, the surveyed companies were very reluctant; only 2 family enterprise out of 14 surveyed companies had actually practiced such issue.

(xviii) Code of Business Ethics:-

So far as disclosure of Corporate Governance Guidelines/ Code of business ethics in organizations was concerned, all the surveyed companies including family enterprises strictly adhered to the issue. Moreover, regarding prescribing a separate code of conduct/ethics for the board members, almost all the surveyed companies had such a code in place.

\section{Individual Company wise Analysis:}

In individual company-wise Corporate Governance Performance, the surveyed companies' endeavour towards promoting good governance has been measured by "Corporate Governance Score"(CGS) (constructed with the help of binary scaling i.e. by putting ' 1 ' for Compliance of any issue and ' 0 ' for Non-compliance/Non-explanation for 
each of the 95 issues considered for the survey taken from 22 nationally/internationally acclaimed Codes of Corporate Governance/ law/clause/provisions or recommendations of Committees for Prescribing Best Practices in Corporate Governance). In the following tables the corporate governance scores of all 30 surveyed companies including top14 family enterprises are presented below-

Corporate Governance Scores of Sample Family Enterprises

\begin{tabular}{|l|l|r|}
\hline Rank & Name of the Family Enterprise & Corporate Governance Scores (CGS) \\
\hline 1 & Reliance Industries Ltd. & 84.2105 \\
\hline 2 & Dr.Reddy's Lab & 83.1579 \\
\hline 3 & Tata Powers & 80 \\
\hline 4 & Wipro & 78.9474 \\
\hline 5 & Bharti Airtel & 76.8421 \\
\hline 6 & Tata Steel & 75.7895 \\
\hline 7 & Mahindra \&Mahindra & 74.7368 \\
\hline 8 & Tata Consultancy Services & 73.6842 \\
\hline 8 & Tata Motors & 73.6842 \\
\hline 10 & Sun Pharma & 69.4737 \\
\hline 11 & Hero Motocorp & 67.3684 \\
\hline 12 & Bajaj Auto & 65.2632 \\
\hline 13 & Hindalco & 64.2105 \\
\hline 14 & Cipla & 51.5789 \\
\hline
\end{tabular}

Source: Calculation based on PROWESS and Corporate Disclosures

Corporate Governance Scores of Sample Non-Family Enterprises

\begin{tabular}{|l|l|r|}
\hline Rank & Name of the Family Enterprise & Corporate Governance Scores (CGS) \\
\hline 1 & Infosys Technologies Ltd & 91.5789 \\
\hline 2 & HDFC & 76.8421 \\
\hline 2 & Larsen \&Toubro & 76.8421 \\
\hline 4 & HDFC Bank & 75.7895 \\
\hline 5 & Axis & 73.6842 \\
\hline 6 & ONGC & 72.6316 \\
\hline 7 & ITC & 71.5789 \\
\hline 7 & Sesa Sterlite & 71.5789 \\
\hline 9 & ICICI Bank & 70.5263 \\
\hline 9 & NTPC & 70.5263 \\
\hline 11 & HUL & 69.4737 \\
\hline 12 & Maruti Udyog Ltd. & 66.3158 \\
\hline 13 & BHEL & 63.1579 \\
\hline 14 & GAIL & 62.1053 \\
\hline 15 & Coal India & 57.8947 \\
\hline 15 & SBI & 57.8947 \\
\hline
\end{tabular}

Source: Calculation based on PROWESS and Corporate Disclosures

\section{Hypothesis Testing:-}

In order to check the degree of difference in Corporate Governance Scores across the surveyed family enterprises, the K-independent samples Kruskal-Wallis test has been used for testing null hypothesis $\mathrm{H}_{0}$ : CGS across the family enterprises are same, against the alternative hypothesis $\mathrm{H}_{1}$ : CGS across the family enterprises are different at $\infty=0.5$. 


\begin{tabular}{|l|l|l|l|}
\hline \multicolumn{2}{|c|}{ Hypothesis Test Summary } \\
\hline \multicolumn{1}{|c|}{ Null Hypothesis } & \multicolumn{1}{|c|}{ Test } & Sig. & Decision \\
\hline \begin{tabular}{|l|l|l|}
\hline $\begin{array}{l}\text { The distribution of Corporate } \\
\text { Governance Score is the same } \\
\text { across categories of Type of the } \\
\text { Company. }\end{array}$ & $\begin{array}{l}\text { Independent- } \\
\text { Samples Kruskal- } \\
\text { Wallis Test }\end{array}$ & $\begin{array}{l}\text { Retain the null } \\
\text { hypothesis. }\end{array}$ \\
\hline Asymptotic significances are displayed. The significance level is .05. \\
\hline
\end{tabular} \\
\hline
\end{tabular}

Independent-Samples Kruskal-Wallis Test

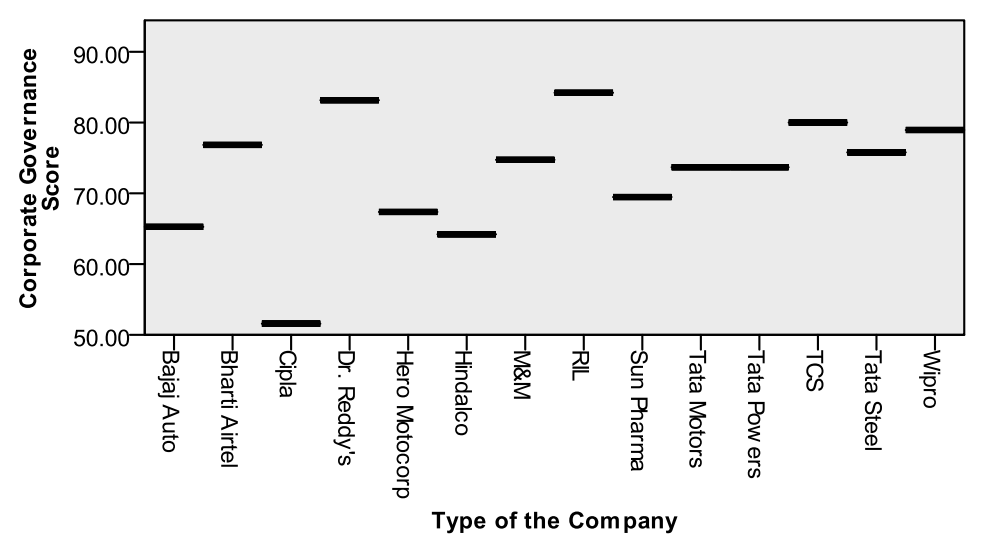

\begin{tabular}{|lr|}
\hline Total N & 14 \\
\hline Test Statistic & 13.000 \\
\hline Degrees of Freedom & 13 \\
\hline Asymptotic Sig. (2-sided test) & .448 \\
\hline
\end{tabular}

1. The test statistic is adjusted for ties.

2. Multiple comparisons are not performed because the overall test does not show significant differences across samples.

Result Generated with the help of IBM SPSS 21

It can be observed that there is no statistical justification to reject the null hypothesis that the corporate governance scores across the surveyed family enterprises are same. Thus the disparities in CGS across surveyed family enterprises are not statistically significant.

In order to test the difference in corporate governance scores between surveyed family enterprises and surveyed non- family enterprises, the Mann-Whitney $\mathrm{U}$ Test has been used for testing null hypothesis of $\mathrm{H}_{0}$ : CGS family enterprises $=\mathrm{CGS}_{\text {non-family enterprises }}$ against alternative hypothesis $\mathrm{H}_{1}$ : CGS family enterprises $\neq \mathrm{CGS}$ non-family enterprises ${ }^{0} \infty=0.05$. 


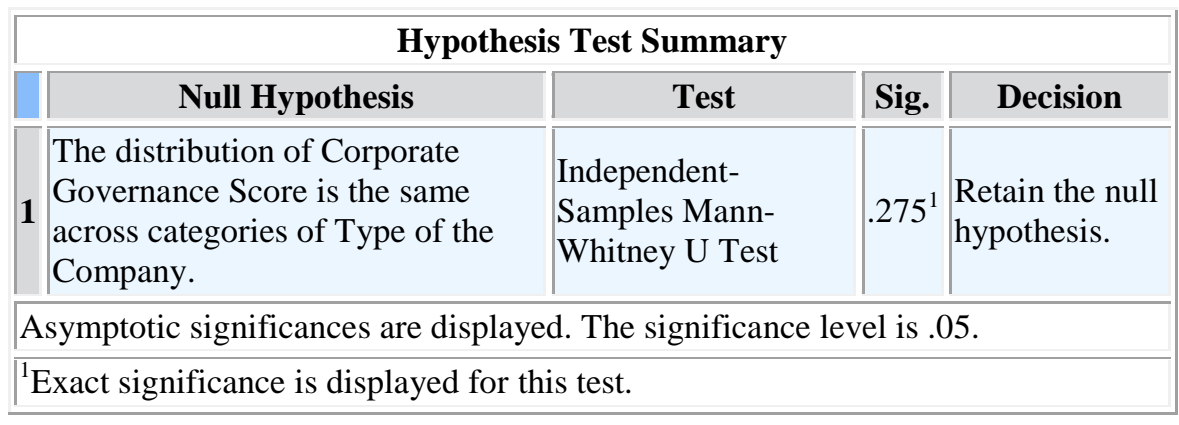

Independent-Samples Mann-Whitney U Test

Type of the Company

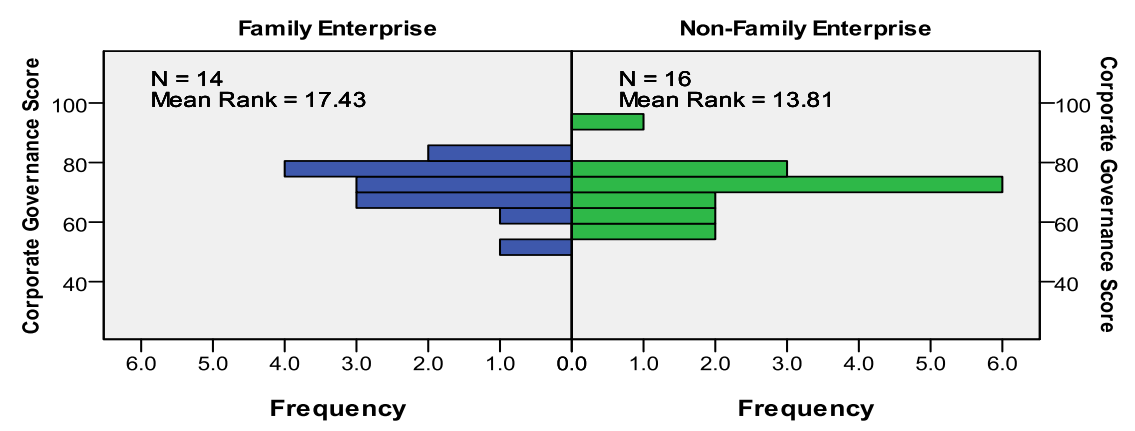

\begin{tabular}{|lr|}
\hline Total N & 30 \\
\hline Mann-Whitney U & 85.000 \\
\hline Wilcoxon W & 221.000 \\
\hline Test Statistic & 85.000 \\
\hline Standard Error & 24.005 \\
\hline Standardized Test Statistic & -1.125 \\
\hline Asymptotic Sig. (2-sided test) & .261 \\
\hline Exact Sig. (2-sided test) & .275 \\
\hline
\end{tabular}

Result Generated with the help of IBM SPSS 21

It can be observed that there is no statistical justification to reject the null hypothesis that the corporate governance scores between the surveyed family and non-family enterprises are same. Thus the disparities in CGS between the surveyed family enterprises and non-family enterprises are not statistically significant.

\section{Policy Recommendations}

Based on the above discussions and observations the policy prescriptions may be drawn with a few remedial measures for good governance for family enterprises operating in India.

- Ensuring independence in board in true spirit,

- Voluntarily setting up of Additional Board Committees,

- Introduction of Cumulative Voting System for protecting minority interests,

- Organizing Training for Directors,

- Effective Implementation of Whistle Blower Policy,

- Evaluation of Directors performance regularly,

- Constructing the Family Council, 
- Organizing Family assembly on regular basis,

- Formation of A council of elders from the family,

- Having a well organized and a separate Family Office,

- Constructing a Family Social Committee etc.

\section{Scope for further Research}

Research on governance practices for family enterprises in India is in primitive stage. Though some of the studies have been made including the present one, there are other important areas that require attention and provide scope for further research.

a) Sector-wise, industry-wise and company-wise survey for governance practices of Indian family enterprises may be envisaged for obtaining better understanding of the subject.

b) A study about governance practices of Indian family enterprises based on magnitude of capital and businesses viz. Large- Cap, Medium- Cap and Small- Cap companies may be undertaken.

c) A study establishing relationship between succession policies, chief executive officer turnovers (for example, CEO layoffs or voluntary resignations) and governance of family enterprises may be undertaken in Indian context.

d) The role and presence of foreign institutional investors (FIIs) in family enterprises and the impact on corporate governance mechanisms can be envisaged.

e) The research on the relevance of practicing 'ethical management' in day-to-day operation and decision making may be judged in light of Indian family enterprise sector and their contribution towards increasing performances of firms should be conducted.

f) A detailed study to establish the relationship between Corporate Governance practices of family-run firms and Corporate Performance may be analyzed.

\section{References}

[1] Almazan, A., Brown, K., Carlson, M., and Chapman, D.(2004). Why constrain your manager?, Journal of Financial Economics ,73(2), 289-321.

[2] Bin Saleh, A. (2006). Corporate Governance of Family Businesses, Art Group Graphic, Cairo, Egypt.

[3] Cadbury, A. (2000). Family Firms and Their Governance; Creating Tomorrow's Company from Today's, Egon Zehnder International, Great Britain.

[4] El-Din, A. G. (2008). Corporate Governance in Family Owned Businesses in Egypt: The Case of Egytrans, Cairo.

[5] Fama, E. (1980). Agency problem and the theory of the firm. Journal of Political Economy, 88, 288-307.

[6] Fama, E. and Jensen, M.(1983). Separation of ownership and control. Journal of Law and Economics, XXVI, June.

[7] Fich, E. and Shivdasani, A. (2006). Are busy boards effective monitors?. Journal of Finance, 61(2),689-724.

[8] Gersick, K. E., Davis, J. A., Hampton, M. M. and Lansberg, I. (1997). Generation to Generation: Life Cycles of the Family Business, Harvard Business Press.

[9] Klein, A.(1998). Firm performance and board committee structure, Journal of Law and Economics ,41, 257-299.

[10] Hermalin, B. and Weisbach, M. (2003). Boards of directors as an endogenously determined institution: a survey of the economic literature. FRBNY Economic Policy Review. April, 7-26.

[11] Herman, E. (1981). Corporate Control, Corporate Power. New York: Cambridge University Press.

[12] Holmstrom, B.(1999) Managerial incentive problems: A dynamic perspective. Review of Economic Studies,66(1), 169182.

[13] Levitt, A. and Dwyer, P. (2002). Take on the Street: What Wall Street and Corporate America Don't Want You to Know, What You Can Do to Fight Back. New York: Pantheon Books.

[14] Lipton, M. and Lorsch, J. (1992). A modest proposal for improved corporate governance. Business Lawyer.

[15] Mace, M. (1986). Directors: Myth and Reality. Boston: Harvard Business School Press.

[16] MacAvoy, P. and Millstein, I.(1999). The active board of directors and its effect on the performance of the large public traded corporation. Journal of Applied Corporate Finance ,11(4), 8-20.

[17] McCracken, K., Woods, M. \& Tee, C. (2009), Governance and management, In J. Sutton \& I. Macdonald (Eds.) Business families and family businesses: The STEP handbook for advisers (pp. 179-192), London: Globe Law \& Business

[18] Mehran, H.(1995). Executive compensation structure, ownership, and firm performance. Journal of Financial Economics, 38 (2), 163-184.

[19] OECD, (2006). Corporate Governance of Non-listed Companies in Emerging Markets, OECD Publishing Paris

[20] Whisler, T. (1984). The Rules of the Game: Inside the Corporate Board Room. Homewood: Dow Jones-Irwin.

[21] Varma, R.( 2003). An empirical examination of sponsor influence over the board of directors. The Financial Review, 38, 55-76. 